\title{
Seasonal Variations in Protein and Mineral Content of Fringed Sagewort [Artemisia frigida]
}

FRANK RAUZI

\section{Abstract}

Fringed sagewort (Artemisia frigida) was collected biweekly from May 15 through October 4, 1979, from a loamy range site near Cheyenne, Wyo. Crude protein, calcium, iron, potassium, magnesium, manganese, phosphorus, sodium, and zinc were determined on the collected plant material. After July 12, leaves and flowers were stripped from the stems and analy zed separately. Crude protein and mineral concentrations in the (fringed sagewort) plant material generally decreased with the advance of the growing season. Except for phosphorus and crude protein content in the stems after ate July, the nutritional value was adequate. Fringed sagewort is considered to be of minor importance but is an important forage plant for wildlife and, to a lesser extent, for livestock use.

Fringed sagewort (Artemisia frigida), also known as fringed sage, fringed sagebrush, and pasture sage, is a perennial half-shrub. The flowers have a camphor like odor, and crushed leaves have an aromatic sage odor.

Fringed sagewort is widely distributed. It extends from Mexico northward through a major portion of the western United States and Canada into Alaska, and thence to Siberia, northern Asia, and Europe (USDA 1937).

Klipple and Costello (1969) stated that fringed sagewort is a common shrub with little forage value, but it is used to a considerable extent by cattle on heavily grazed pastures and only sparingly under moderate and light grazing. Johnson (1956) found that fringed sagewort was not grazed until the more palatable species had been heavily utilized, and that production of fringed sagewort was higher on heavily grazed areas than on moderately or lightly grazed areas. Reed and Peterson (1961) stated that indiscriminate use of fringed sagewort as an indicator of range deterioration seems unwise, as the abundance of this shrub may be strongly correlated with weather patterns. Wight (1976) found that fringed sagewort on mixed prairie rangeland showed a marked initial response to nitrogen $(\mathrm{N})$ fertilization at nearly all rates. Goetz (1969) reported that fringed sagewort responded consistently to fertilization of native rangeland.

The forage value of fringed sagewort varies with location, soils, time of year, and grazing animal. On western ranges it usually rates good to fair for sheep, fairly good for cattle, and fair for deer (Odocoileus hemionus) and elk (Cervus canadensia) (USDA 1937). Rietz and Morris (1939) reported palatability ratings for fringed sagewort of $10 \%$ for cattle and horses and $20 \%$ for sheep and goats. Cole (1956) stated that fringed sagewort was one of the principal browse species for the pronghorn antelope (Antilocapra americana). Vavra et al. (1977) found that blue grama was the principal component of cattle diets, with fringed sagewort ranking lower in preference and making up $2 \%$ of all diets and was the only plant which ranked lower in palatability than blue grama for the 12 most important foods of cattle.

The chemical composition of browse species can vary with soil fertility, stage of growth, climate, and inherent characteristics of the species. Since little information is available about seasonal changes in fringed sagewort, a study was conducted to evaluate the mineral and crude protein of fringed sagewort for the 1979 growing season near Cheyenne, Wyo.

\section{Study Area and Procedure}

The study area was located on the Lummis ranch about $8 \mathrm{~km}$ south of Cheyenne, Wyo., on U.S. highway 85 . The elevation of the site is about $1,859 \mathrm{~m}$. The aea from which the fringed sagewort was

\footnotetext{
Author is soil scientist (retired), Strip Mine Reclamation, USDA, Agr. Res., 8408 Hildreth Rd., Cheyenne, Wyo. 82009.

This research was preformed in cooperation with the Univ. of Wyoming Exp. Sta., and approved as Journal Article \#1094.
}

Manuscript received October 3, 1980 collected was contour furrowed in the late fall of 1977.

Native vegetation is characteristic of the shortgrass plains. Dominant species are blue grama (Bouteloua gracilis), western wheatgrass (Agropyron smithii), and dryland sedges (Carex spp). Other grasses and forbs present on the site are of minor importance in the composition. The soil was Ascalon fine sandy loam, a member of the fine loamy, mixed mesic family of Aridic Arguistolls. The Ascalon soil has developed in alluvial sediments on level to nearly level alluvial fans and low terraces.

Entire plants of fringed sagewort were collected biweekly from May 15 through October 4, from numerous plants at each collection date and composited. Starting July 12, leaves and flowers were stripped from the stems. The plant material was oven-dried at $67^{\circ} \mathrm{C}$ for 24 hours and ground in a Wiley mill (with stainless steel chamber, screen, and blades) equipped with a 40-mesh screen. Crude protein was determined as total $\mathrm{N} \times 6.25$ by the Kjeldahl procedure (Biochemistry Division, University of Wyoming). Phosphorus (P) was determined by the Vanadomolybdophoric yellowcolor method in a nitric acid system (Jackson 1958). Calcium (Ca), iron ( $\mathrm{Fe}$ ), potassium, (K), magnesium ( $\mathrm{Mg}$ ), manganese ( $\mathrm{Mn}$ ), sodium ( $\mathrm{Na})$, and zinc $(\mathrm{Zn})$ were determined by atomic absorption spectrophotometry on a percholoric acid digest. All data are reported on a dry-weight basis and are an average of 2 samples.

The nearest weather station is located at the University of Wyoming's Archer Research Extention Center, about 8 km northeast of the collection site. Precipitation for April through September amounted to $263.6 \mathrm{~mm}$, and the May and June rains accounted for 48.5 and $74.4 \mathrm{~mm}$, respectively. During August, 71.9 $\mathrm{mm}$ of rain was recorded. Most plant growth occurred earlier, but plants remained green through August.

\section{Results and Discussion}

Crude protein and mineral concentrations in the fringed sagewort plant material decreased with maturity. The amount and distribution of the spring and summer rains may have influenced growth and crude protein and mineral concentrations. (Protein is considered to be one of the most important nutrients, as it is essential for growth, weight gain, and lactation,) The protein requirement of wild animals is probably equal to that of domestic animals (Halls 1970). Concentration of crude protein was highest on May 30, and then decreased sharply in the stems and more slowly in the leaves (Figure 1). The crude protein concentration in the leaves was sufficient for most classes of livestock, whereas the stems were deficient (National Research Council 1975, 1976).

Calcium and $K$ concentrations were more than adequate for livestock nutrition throughout the sampling period, whereas $P$ concentration in the stems was not adequate between August 9 and September 20 , leaves were borderline at 3 of those 4 sampling dates. The principal function of $\mathrm{Ca}$ and $\mathbf{P}$ is in skeleton formation. Potassium, $\mathrm{Na}, \mathrm{Mg}, \mathrm{Fe}, \mathrm{Mn}$, and $\mathrm{Zn}$ function as constituents of enzyme activators, and only small amounts are required (Dietz 1970). The $\mathrm{Ca}$ requirement (percent dry matter consumed) is between 0.22 and $0.34 \%$ for sheep and 0.18 to $0.22 \%$ for cattle (National Research Council 1975, 1976). The Ca concentrations ranged from 7 to $31 \%$ less in the stems than in the leaves. Phosphorus requirements set by the National Research Council (1975, 1976) are $0.16,0.20$ and $0.16 \%$ for sheep, dry and pregnant cows, and lactating cows, respectively. The p concentrations for the first 6 sampling dates (May 15 through July 26) were adequate for all classes of livestock. The National Research Council has not established a minimum $K$ requirement for sheep, but 0.6 to $0.8 \%$ is suggested for growing and finishing steers. Thus, the $K$ concentrations in the leaves and stems were more than adequate during the sampling period. 


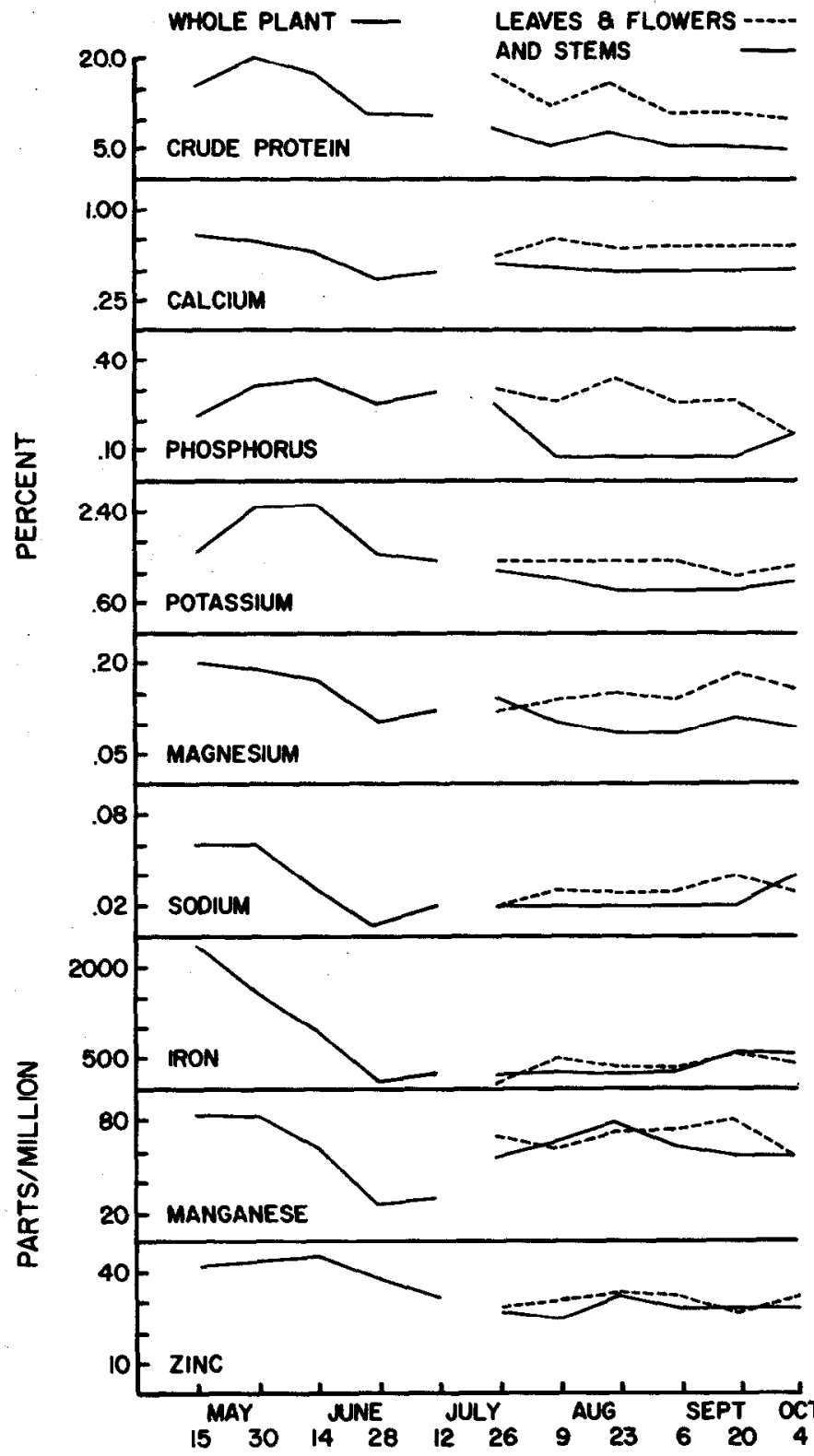

Fig. 1. Crude protein and mineral composition of fringed sagewort (Artemisia frigida) sampled at 2-week intervals from May 15-October 14, 1979, from a native shortgrass range site 5 miles south of Cheyenne, Wyo.

Magnesium is essential for all classes of livestock and wildife. "Magnesium is closely associated with the utilization of $\mathrm{Ca}$ and $\mathrm{P}$, is necessary for proper action of many enzyme systems, plays a vital role in carbohydrate metabolism and aids in the proper function of the nervous system," (Hamilton and Gilbert 1972). The National Research Council suggests an $\mathrm{Mg}$ intake of $0.6 \%$ of the diet dry matter for adult ewes and 0.4 to $0.10 \%$ for growing steers and heifers. The magnesium concentrations were $47 \%$ lower in the stems than in the leaves of the fringed sagewort during the sampling period.

The $\mathrm{Na}$ concentrations of fringed sagewort whole-plant material and the separated leaves and stems ranged from 0.01 to $0.06 \%$ and averaged $0.03 \%$. Sodium is necessary for life, and usually animals do not obtain enough $\mathrm{Na}$ through the forage they eat; instead they obtain it from salt supplied by the farmer or natural salt licks.

Iron, $\mathrm{Mn}$, and $\mathrm{Zn}$ concentrations in the leaves and stems decreased from May to June or later. Iron concentrations showed a large decrease and then fluctuated from late June on. At the last two sampling dates, in September and October, Fe concentrations were higher in the stems than in the leaves. The Fe concentration in the stems and leaves was adequate for animal nutrition, as the range is $\mathbf{4 0}$ to $\mathbf{4 0 0} \mathrm{ppm}$ (Hamilton and Gilbert 1972). Manganese concentration was lowest on June 28; the low Mn concentration may have results from dilution, as this may have been a period of rapid growth. The National Research Councl $(1975,1976)$ requirement for $\mathrm{Mn}$ is $0.5 \mathrm{ppm}$, so the $\mathrm{Mn}$ concentration in the fringed sagewort was more than adequate for sheep and cattle. Zinc concentrations in the leaves ranged from 28 to $34 \mathrm{ppm}$ between July 26 and October 4 . The Zinc requirement for sheep is $20 \mathrm{ppm}$, and 46 ppm is probably adequate for cattle (Blincoe and Lambert 1972). Thus, the zinc concentrations in the stems and leaves were adequate for sheep but not for cattle or nearly so.

On ranges in good condition, fringed sagewort is of minor importance and is generally not grazed until the more palatable species have been utilized. The chemical analysis of a whole-plant does not adequately indicate the nutritive value, as animals are highly selective about plant parts they eat. Except for $P$ and protein concentrations in the stems after late July, the nutritional value of fringed sagewort remained high and adequate for livestock nutrition. Cole (1956) showed that the principal browse species of pronghorn antelope were sagebrush, fringed sagewort, and silver sage (Artemisia cana); big sage (Artemisia tridentata) amounted to $70 \%$ of the rumen sample by weight. Goodwin (1975) found that fringed sagewort consistently made up $6 \%$ of the deer's diet during the fall in southwestern Wyoming. Thus, fringed sagewort is used by wildlife and it can also provide some forage nutritious to livestock.

\section{Literature Cited}

Blincoe, C., and T.L. Lambert. 1972. Micronutrient trace elment composition of crested wheatgrass. J. Range Manage. 25:128-130.

Cole, G.F. 1956. The pronghorn antelope. Its range and use and food habits in central Montana with special reference to alfalfa. Montana State. Coll. Agr. Exp. Sta. Tech. Bull. 516, 63 p.

Dietz, D.R. 1970. Animal production and forage quality. Range and wildlife habitat evaluation, a research symposium. USDA-FS Misc. Pub. \#1147, p. 1-9.

Goetz, H. 1969. Composition and yields of native grassland sites fertilized at different rates of nitrogen. J. Range Manage. 22:384-390.

Goodwin, G.A. 1975. Seasonal food habits of mule deer in southeastern Wyoming. USDA-FS, Note RM 287, 4 p.

Halk, L.K. 1970. Range and wildlife habitat evaluation, a research symposium. USDA-FS Misc. Pub. \#1147, p. 10-24.

Hamilton, J.W., and C.S. Gilbert. 1972. Composition of range plants and soils. Wyoming Agr. Exp. Sta. Res. J. 55, 14 p.

Jackson, M.L. 1958. Soil chemical analysis. Prentice Hall Inc., Englewood Cliffs, NJ p. 151-153.

Johnson, W.M. 1956. The effect of grazing intensity on plant composition, vigor, and growth of pine bunch grass ranges in central Colorado. Ecology 37:790-798.

Klipple, G.E., and D.F. Costello. 1960. Vegetation and cattle response to different intensities of grazing on shortgrass ranges on the Central Great Plains. USDA, Tech. Bull. \#1216, 82 p.

National Academy of Science and National Research Council. 1975. Nutrient requirements of domestic animals \#5. Fifth revised edition. Nutrient requirement for sheep. National Research Council, Washington, D.C., $72 \mathrm{p}$.

National Academy of Science and National Research Council. 1976. Nutrient requirements of domestic animals \#4. Fifth revised edition. Nutrient requirements of beef cattle. Nat. Res. Council, Washington, D.C. 56 p.

Reed, M.J., and R.A. Peterson. 1961. Vegetation soil and cattle response to grazing on Northern Great Plains range. USDA, Forest Serv. Tech. Bull. $1252,79 \mathrm{p}$.

Reitz, L.P., and H.E. Morris. 1939. Important grasses and other common plants on Montana ranges. Montana State Coll. Agr. Exp. Sta. Bull. 375, $35 \mathrm{p}$.

USDA. 1937. Range handbook. Prepared by the Forest Service, reproduced by Nat. Tech. Info. Serv.

Vavra, M., R.W. Rice, R.M. Hansen, and P.L. Sims. 1977. Food habits of cattle on shortgrass range in Northeastern Colorado. J. Range Manage. 30:261-263.

Wight, R.J. 1976. Range fertilization in the Northern Great Plains. J. Range Manage. 29:180-185. 